\title{
MINERALOGY OF KIMBERLITE BOULDERS FROM ESKERS IN THE KIRKLAND LAKE AND LAKE TIMISKAMING AREAS, NORTH-EASTERN ONTARIO, CANADA
}

\author{
Ingrid Kjarsgaard ${ }^{1}$, Beth McClenaghan ${ }^{2}$, Bruce Kjarsgaard ${ }^{2}$, and Larry Heaman ${ }^{3}$ \\ ${ }^{1}$ Consulting Mineralogist, Canada; ${ }^{2}$ Geological Survey of Canada, Canada; ${ }^{3}$ University of Alberta, Canada
}

\section{INTRODUCTION}

Sixteen kimberlite boulders were collected from three sites on the Munro and Misema River eskers in the Kirkland Lake kimberlite field (Fig. 1), and one site on the Sharp Lake esker in the Lake Timiskaming kimberlite field (Fig. 2 ), in order to investigate glaciofluvial transport of kimberlitic material and to see if it could be traced to known kimberlites in the region.

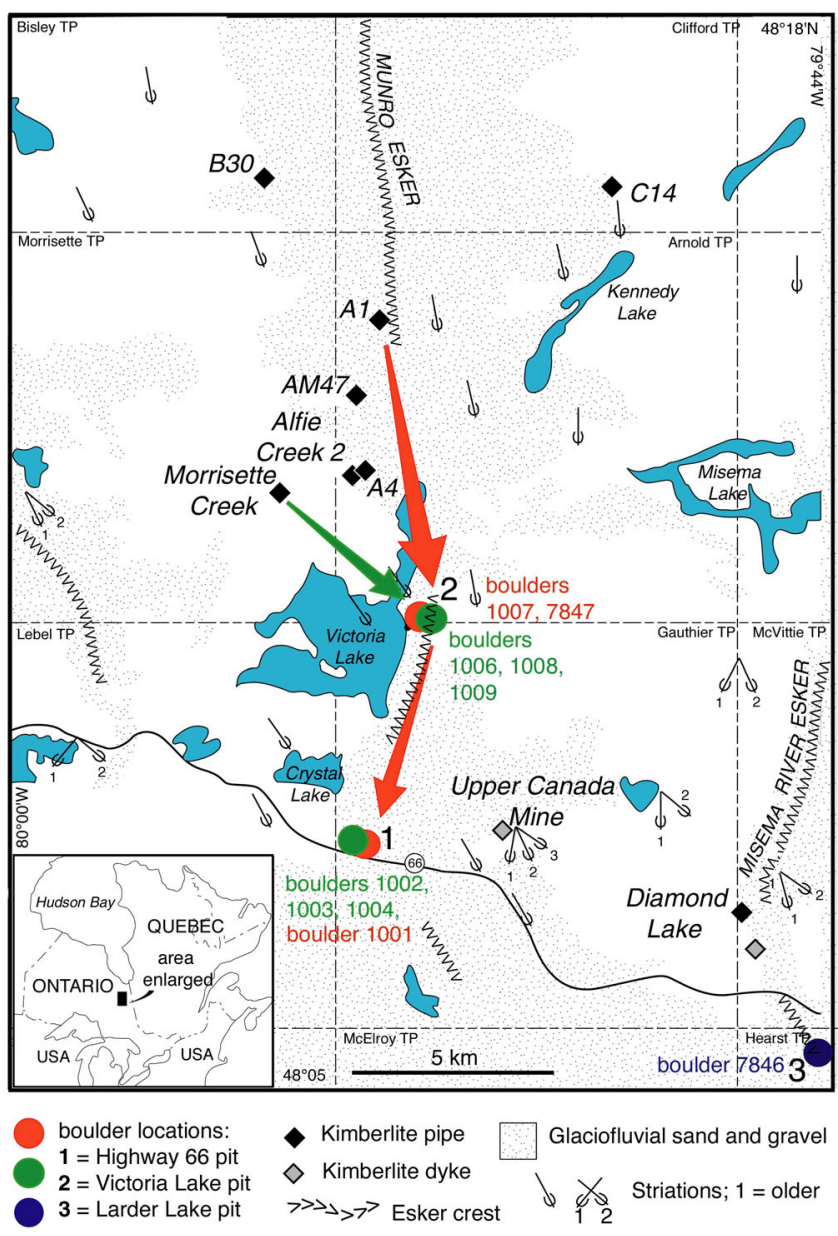

Figure 1: Boulder sample sites with glaciofluvial features and location of known kimberlites in the Kirkland Lake area, northeastern Ontario, Canada.

The boulders were processed for heavy mineral concentrates, from which Mg-ilmenite, chromite, garnet, clinopyroxene, olivine and perovskite were picked and analyzed by microprobe. $\mathrm{U} / \mathrm{Pb}$ age dating was carried out on perovskite concentrates from selected boulders.

Based on relative indicator mineral abundances and composition, the boulders could be assigned to six different groups, four for the Munro Esker and one for the Misema River esker in the Kirkland Lake area, and one for the Sharp Lake samples from the Lake Timiskaming kimberlite field. Mg-ilmenite and garnet compositions from megacrysts and eclogites were particularly useful in characterizing different groups of boulders and tracing them to their potential kimberlite sources, whereas olivine, Cr-diopside and chromite were less useful, being from lherzolitic peridotite that was sampled by all kimberlites in the region.

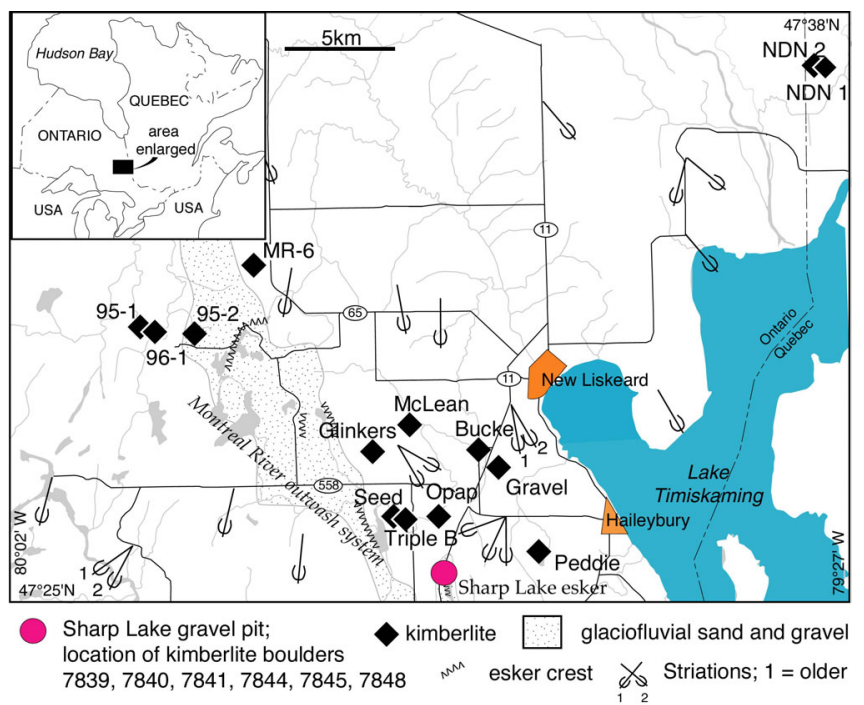

Figure 2: Boulder sample sites with glaciofluvial features and location of known kimberlites in the Lake Timiskaming area, northeastern Ontario, Canada.

\section{RESULTS}

The six groups of boulders have the following characteristics:

Group I (samples 1002, 1003, 1004, 1006, 1008 and 1009) from two locations on the Munro esker contain abundant fresh olivine, chromite, $\mathrm{Cr}$-diopside and $\mathrm{Mg}$-ilmenite, and moderate garnet. These samples also contain pargasitic 
amphibole and coarse perovskite. Their Mg-ilmenite compositions define tight clusters with a narrow range of $\mathrm{MgO}$ (10 to 13 wt.\%) and $\mathrm{Cr}_{2} \mathrm{O}_{3}$ (0 to 1.2 wt.\%) (Fig. 3a). Garnet compositions include lherzolitic (G9) Cr-pyrope with up to $8 \mathrm{wt} . \% \mathrm{Cr}_{2} \mathrm{O}_{3}$, a distinct population of subcalcic $\begin{array}{lllll}\text { pyrope with around } 2 & \text { wt. } \% & \mathrm{Cr}_{2} \mathrm{O}_{3} & \text {; } & \text { Ti-Cr-pyrope }\end{array}$ megacrysts and numerous almandine-grossular garnets of both eclogitic and crustal origin (Fig. 3b). Group I boulders resemble the Morrisette Creek and B30 kimberlites of the Kirkland Lake kimberlite field, which have similar relative abundances of indicator minerals and also contain pargasitic amphibole (Sage, 1996). The Mgilmenite compositions of the boulders, however, do not match those from B30. Unfortunately, there is only one published Mg-ilmenite analysis available for the Morrisette Creek kimberlite (Fig. 3c). Both B30 and especially Morrisette Creek also contain almandine-grossular garnets which have not been found in other kimberlites in the Kirkland Lake area (Fig. 3d). U/Pb ages for three of the boulders range between $157.8 \pm 4.8$ and $159.6 \pm 4.8 \mathrm{Ma}$, which is well within the range of dated kimberlites in the Kirkland Lake area (A1, A4, AM47, B30, C14 and Morrisette Creek; Heaman \& Kjarsgaard, 2000). Based on the characteristic populations of eclogitic and crustal garnet, as well as the occurrence of pargasitic amphibole and coarse perovskite we suggest the Morrisette Creek kimberlite as the source for the boulders, but a paucity of published Mg-ilmenite data from this kimberlite does not allow a firm conclusion. Morrisette Creek is situated 5 to 9 kilometers up-ice of the Group I boulder sample sites (Fig. $1)$.

Group II (sample 1001), III (sample 1007) and IV (sample 7847) are from the same localities on the Munro esker as the Group I boulders. They have some similarities with each other but are not as homogeneous a group as the Group I boulders. They differ in abundances and compositions of indicator minerals: boulder 1001 lacks chromite but contains abundant olivine, boulder 1007 contains more garnet than oxides but little $\mathrm{Cr}$-diopside and olivine; boulder 7847 has very high abundances of both garnet, Mg-ilmenite, chromite and $\mathrm{Cr}$-diopside but hardly any olivine. Mg-ilmenite compositions in these three boulders are generally similar, with 10.5 to 14 wt.\% $\mathrm{MgO}$ and low $\left(<0.6\right.$ wt.\%) $\mathrm{Cr}_{2} \mathrm{O}_{3}$ except for some outliers which are different in each sample (Fig. 4a, c, e). Similar Mgilmenite compositions are also found in the A1 kimberlite (Sage, 1996; Fig. 4g). Garnet compositions are slightly different for each sample: 1001 and 1007 contain abundant (fragmented) megacryst garnet and less lherzolitic (G9) garnet (Figs. 4b and d); 1001 also contains abundant websteritic garnet which is absent in the other samples. $\mathrm{U} / \mathrm{Pb}$ perovskite ages for boulder samples 1001 and 1007 of $157.9 \pm 4.2 \mathrm{Ma}$ and $157.3 \pm 2.9 \mathrm{Ma}$, respectively, are within error of the known age of the A1 kimberlite (158.9 \pm 3.7 Ma). Although the three samples are treated as potentially coming from three different sources, their Mg- ilmenite and garnet compositions all show similarities with the A1 kimberlite. Boulder 7847 shows the closest resemblance to the A1 kimberlite, which is located immediately adjacent to the Munro Esker 9 to $14 \mathrm{~km}$ directly up ice from the sample locations.

Group V is represented by a single boulder sample (7846) from the Misema River esker, S of Diamond Lake in the Kirkland Lake kimberlite field (Fig. 1). It is very indicator mineral-poor compared to the other samples. Apart from fresh olivine, the most abundant indicator mineral is $\mathrm{MgO}-$ rich ilmenite with 10 to $17 \mathrm{wt} \% \mathrm{MgO}$, including a few grains with fairly high $\mathrm{Cr}_{2} \mathrm{O}_{3}$ (Fig. 5a). The few garnet grains recovered from this sample all have the same $\mathrm{Cr}$ poor composition indicating that they might be from a single disintegrated grain (Fig. 5b). These indicator mineral characteristics are distinctly different from those of the nearby Diamond Lake kimberlite (McClenaghan et al., 1998) and unlike any other known kimberlite in the Kirkland Lake area (McClenaghan et al., 1996, 1998, 1999a and b; Sage, 1996).

Six samples $(7839,7840,7841,7843,7845,7848)$ from the Sharp Lake esker in the Lake Timiskaming area form Group VI, which is characterized by comparatively Ti-poor megacryst garnets (Fig. 5d), an abundance of coarse perovskite, and a wide range and distinctive pattern in their ilmenite compositions (Fig. 5c). The latter has no match in any of the more than 20 different kimberlites in either the Kirkland Lake or Lake Timiskaming fields analyzed to date (Schulze et al., 1995; McClenaghan et al., 1996, 1998, 1999a, b and c; Sage, 1996, 2000 and unpublished data).

$\mathrm{U} / \mathrm{Pb}$ perovskite ages for two samples from this group yielded indistinguishable ages of $144.7 \pm 1.0 \mathrm{Ma}$. This age falls in the middle of the known range (133 to $155 \mathrm{Ma})$ determined for kimberlites in the Lake Timiskaming area (Heaman \& Kjarsgaard, 2000) but does not match the age of any individual kimberlite.

\section{CONCLUSIONS}

Based on indicator mineral abundances and chemistry (particularly of garnet and Mg-ilmenite) as well as $\mathrm{U} / \mathrm{Pb}$ perovskite ages, only about half of the boulders analyzed can be tentatively linked to known kimberlites in the Kirkland Lake area: six samples from Group I to Morrisette Creek kimberlite (pending additional ilmenite data for this pipe) and one or more boulders of group II, III and IV to the A1 kimberlite. No match was found for boulder 7846 from the Misema River esker nor the six boulders from the Sharp Lake pit in the Lake Timiskaming kimberlite field. It can therefore be concluded that there are more kimberlites to be discovered both in the Kirkland Lake and the Lake Timiskaming kimberlite fields.

\section{REFERENCES}


Heaman, L.M. and Kjarsgaard, B.A., 2000. Timing of eastern North American kimberlite magmatism: continental extension of the Great Meteor hotspot track. Earth and Planetary Science Letters 178, 253-268.

McClenaghan, M.B., Kjarsgaard, I.M., Schulze, D.J., Stirling, J.A., Pringle, G. and Berger, B.R. 1996. Mineralogy and geochemistry of the B30 kimberlite and overlying glacial sediments, Kirkland Lake, Ontario; Geological Survey of Canada, Open File 3295, 245 p.

McClenaghan, M.B., Kjarsgaard, I.M., Schulze, D.J., Stirling, J.A., Pringle, G. and Berger, B.R. 1998. Mineralogy and geochemistry of the Diamond Lake kimberlite and associated esker sediments, Kirkland Lake, Ontario; Geological Survey of Canada, Open File 3576, 200 p.

McClenaghan, M.B., Kjarsgaard, I.M., Stirling, J.A., Pringle, G., Kjarsgaard, B.A., and Berger, B. 1999. Mineralogy and geochemistry of the $\mathrm{C} 14$ kimberlite and associated glacial sediments, Kirkland Lake, Ontario; Geological Survey of Canada, Open File 3719, 147 p.

McClenaghan, M.B., Kjarsgaard, I.M., Kjarsgaard, B.A., Stirling, J.A., Pringle, G. and Berger, B. 1999. Mineralogy and geochemistry of the A4 kimberlite and associated glacial sediments, Kirkland Lake, Ontario; Geological Survey of Canada, Open File 3769, 162 p.

McClenaghan, M.B., Kjarsgaard, B.A., Kjarsgaard, I.M., Paulen, R.C. , Stirling, J.A. 1999. Mineralogy and geochemistry of the Peddie kimberlite and associated glacial sediments, Lake Timiskaming, Ontario; Geological Survey of Canada, Open File 3775,190 p.

McClenaghan, M.B., Kjarsgaard, I.M., Kjarsgaard, B.A. and Heaman, L.M., 2002. Mineralogy of kimberlite boulders from eskers in the Lake Timiskaming and Kirkland Lake areas, northeastern Ontario. Geological Survey of Canada Open File 4361, 25p. + CD-ROM.

Sage, R.P. 1996. Kimberlites of the Lake Timiskaming Structural Zone; Ontario Geological Survey, Open File Report 5937 , $435 \mathrm{p}$.

Sage, R.P. 2000. Kimberlites of the Lake Timiskaming Structural Zone: Supplement. Ontario Geological Survey, Open File Report, 123 p.

Schulze. D.J., Anderson, P.F.N., Hearn B.C., and Hetman, C.M. 1995, Origin and significance of ilmenite megacrysts and macrocrysts from kimberlite. International Geology Review, v. $37,780-812$.

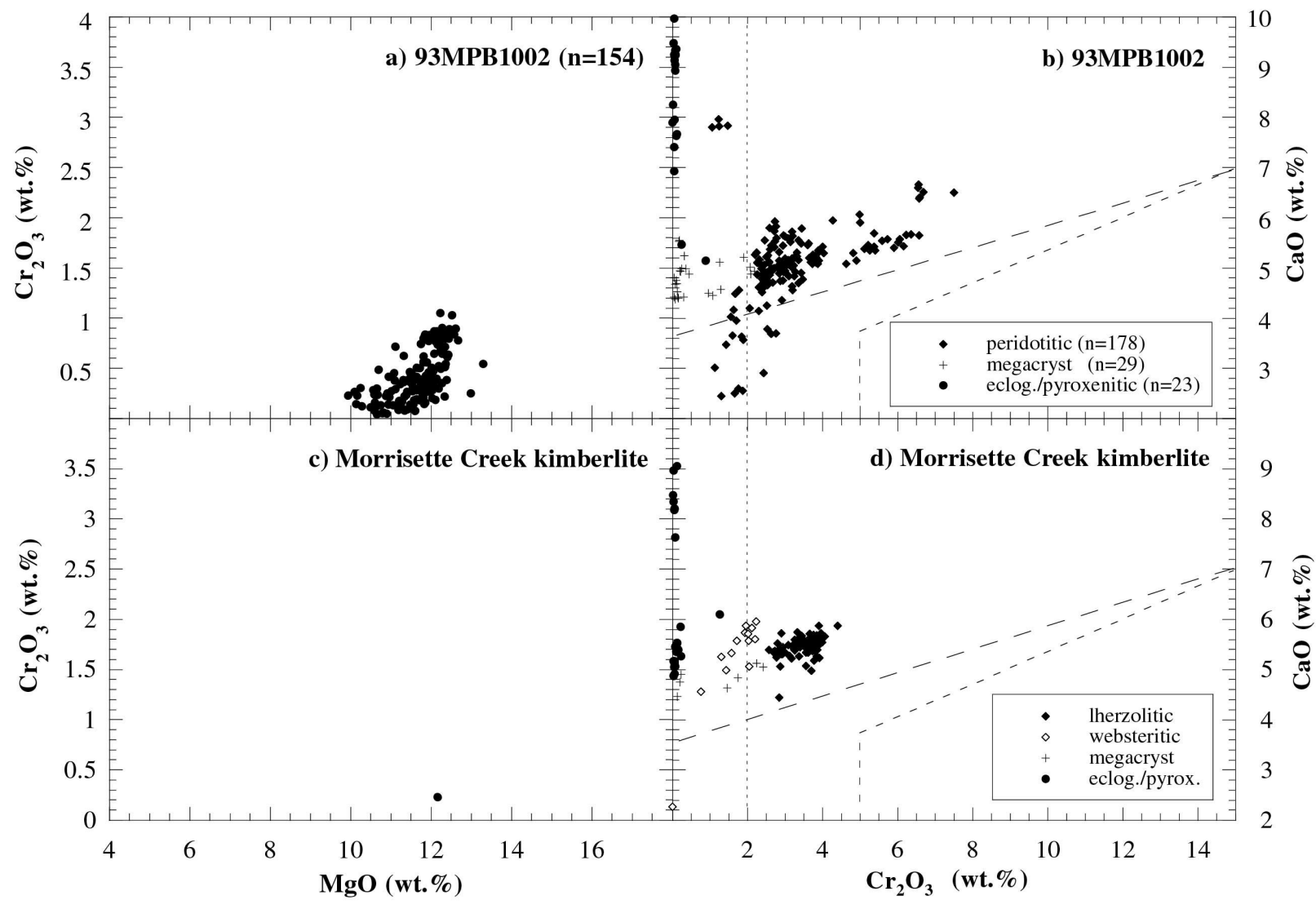

Figure 3: Mg-ilmenite (a) and garnet (b) chemistry of boulder sample 1002, representative of Group I boulders, compared to Mg-ilmenite (c) and garnet (d) chemistry from the Morrisette Creek kimberlite (data for Morrisette Creek from Sage, 1996). 


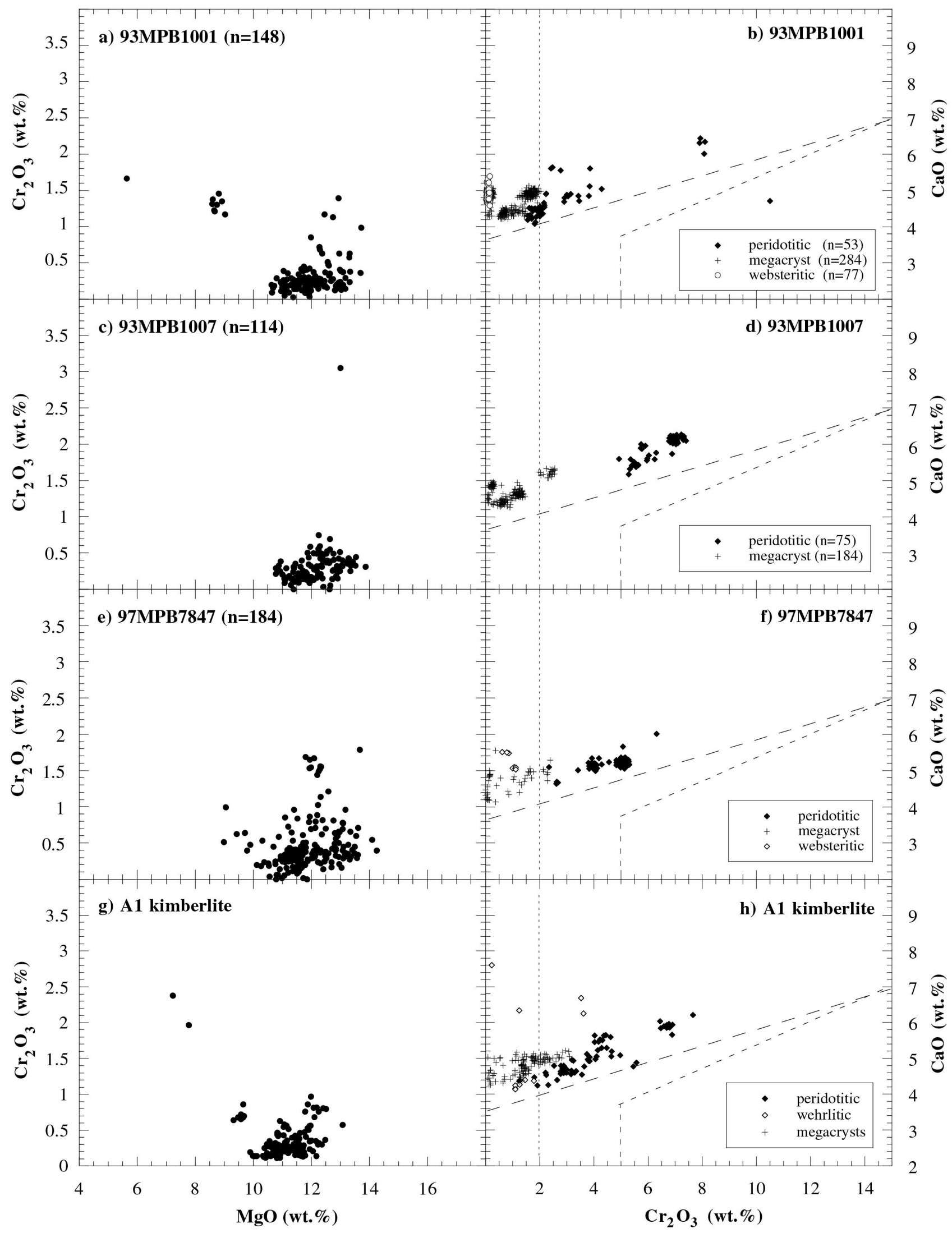

Figure 4: Mg-ilmenite (a, c, e) and garnet (b, d, f) chemistry of boulder samples 1001 (Group II), 1007 (Group III), and 7847 (Group IV), compared to Mg-ilmenite (g) and garnet (h) chemistry from the A1 kimberlite (data for A1 from Sage, 1996). 


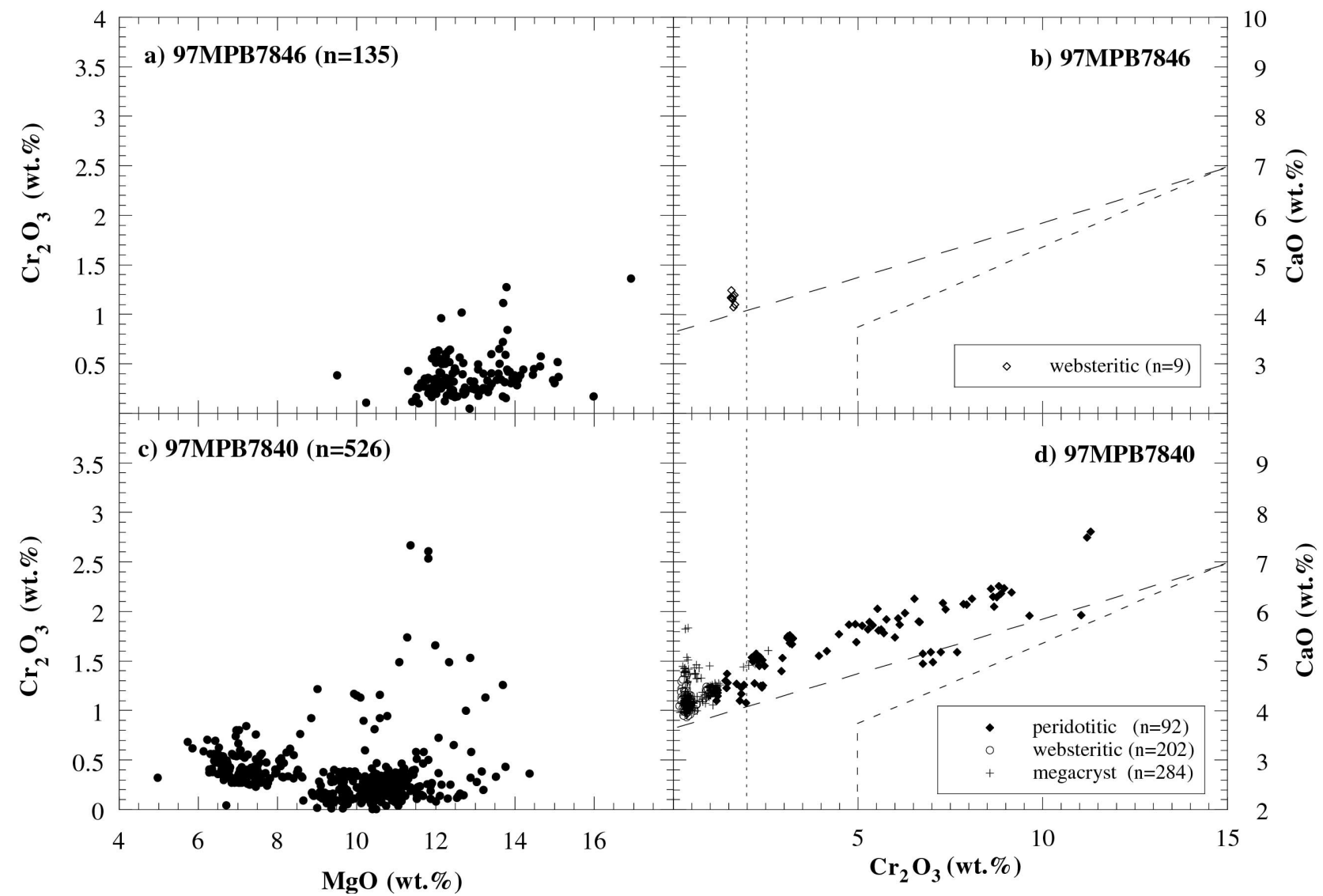

Figure 5: Mg-ilmenite (a, c) and garnet (b, d) chemistry of boulder samples 7846 (Group V) and 7840 (representative of Group VI).

Contact: Ingrid Kjarsgaard, 15 Scotia Place, Ottawa, Ontario, K1S 0W2, Canada; ikjarsgaard@sympatico.ca 